\title{
Congenital orbital teratoma. Case report
}

\section{Teratoma orbitario congénito. Informe de caso}

\author{
Cristina González, MD1, Carlos A. Restrepo, MD1, Gloria I. Salazar, MD², Patricia Monsalve, MD²
}

\section{Summary}

Orbital teratoma is a rare tumor composed of tissue derived from the three germinal layers, it usually occurs in otherwise healthy newborns as a fluctuating mass in orbit, with extreme proptosis and periorbital deformity. There are few reports in literature about this topic; we present a case report with severe stretching and deformity of periocular tissue, which underwent enucleation and careful removal of the tumor, properly sparing the eyelids and other structures in the anophthalmic cavity to fit an ocular prosthesis. It did well, improving the patient's cosmetic appearance and preserving his orbitofacial development. Even though in many cases it is not possible to preserve visual function in patients with congenital orbital teratoma, it is equally important to achieve the best possible cosmetic result.

\section{Keywords: Orbit; Teratoma; Eye enucleation.}

Colomb Med. 2012; 43: 82-85

\section{Resumen}

El teratoma orbitario es un tumor raro compuesto de tejidos derivados de las tres capas germinales, por lo general ocurre en los recién nacidos sanos como una masa fluctuante en órbita, con proptosis extrema y deformidad del tejido periorbitario. Hay pocos informes en la literatura sobre este tema; se presenta un caso clínico con severo estiramiento y deformidad de los tejidos perioculares, a quien se realizó la enucleación y remoción cuidadosa del tumor, respetando adecuadamente los párpados y demás estructuras de la cavidad anoftálmica para adaptar una prótesis ocular. Se logró mejorar el aspecto estético y preservar el desarrollo orbitofacial. Aun cuando en muchos casos no es posible preservar la función visual en pacientes con teratoma orbitario congénito, es importante alcanzar el mejor resultado cosmético posible.

\section{Palabras clave: Órbita; Teratoma; Enucleación del ojo.}

Colomb Med. 2012; 43: 82-85

Congenital orbital teratoma is a rare tumor, which produces severe unilateral proptosis associated with exposure keratopathy ${ }^{1,2}$. Teratomas are considered benign tumors, composed of tissue derived from the three germinal layers ${ }^{3}$. Despite their rapid growth, they are rarely malignant. The most common locations are gonadal, sacrococcygeal, retroperitoneal, and mediastinal regions. Teratomas of the head and neck represent $9 \%$ of all teratoma cases, and orbital compromise is uncommon ${ }^{3,4}$. The eye is commonly well developed but vision is not preserved either due to exposure keratopathy or secondary optic atrophy. The objective in the management of orbital teratoma is to save the eye to encourage orbitofacial development, maintain cosmesis and retain some vision $^{1}$. We report a case of a male newborn with

Associate Professor, Universidad Pontificia Bolivariana, Medellín, Colombia. e-mail:crissagonzalez@yahoo.com carlosrestrepo@hotmail.com Ophthalmology resident, Hospital Pablo Tobón Uribe, Universidad Pontificia Bolivariana. Medellín, Colombia. e-mail: atabel@hotmail.com monsalve81@hotmail.com

Received for publication February 28, 2011 Accepted for publication October 3, 2011 
massive congenital teratoma who underwent a successful surgical resection of the tumor, sparing eyelids and other orbital structures for subsequent adaptation of ocular prosthesis. Even though it was not possible to maintain any vision, a good cosmesis and orbitofacial development could be achieved.

\section{Case report}

A 2,800-gram boy, born in a rural area at 37 weeks gestation by vaginal delivery and with no prenatal history of importance was referred to our Institution $7 \mathrm{~h}$ after birth with a left orbital mass.

The patient was evaluated by the Ophthalmology and Pediatric groups, finding a large vascularized mass compromising the left midface, hard and soft areas in consistence and without pain to palpation; there was a complete proptosis, chemosis, hypopyon and leuchoma, with evident corneal penetration, without any motility of the globe and absence of pupillary reflex (Figure 1). The right eye was normal, with no other lesions in an otherwise healthy newborn; there was no other evidence of germ cell abnormality.

Craneal computerized tomography reported a predominantly cystic, multilocular mass, with calcifications, covering the whole orbital cavity with expansion of the bony walls without dilation of the optical channel and complete forward displacement of the eyeball, without extension to surrounding structures. The right orbit revealed no lesions.

The Magnetic Resonance Imaging (MRI) showed a $6 \times 6 \mathrm{~cm}$ multilocular mass, with liquid and fatty content, without brain lesions (Figure 2). The diagnosis of a teratoma compatible mass was made.

With this history and images, the patient was taken to surgery where a penetrated left eyeball was found and the following procedures were performed: resection of the tumor and enucleation, adaptation of a number 18 Medporimplant with muscle attachment to it, tenon and conjunctiva closure, adjustment of a conformer and tarsorraphy. There were no complications during the procedure. The mass was well defined, encapsulated with areas of hard and soft

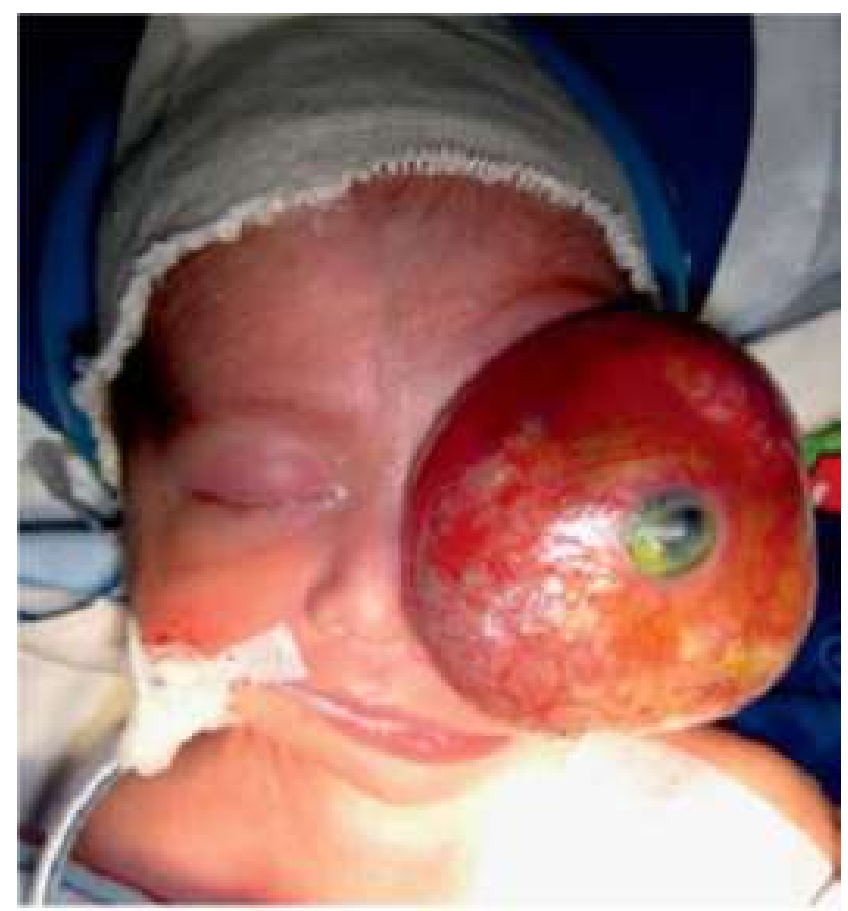

Figure 1. Frontal picture showing vascularized mass, chemosis, complete eyeball exposure and widespread corneal opacity

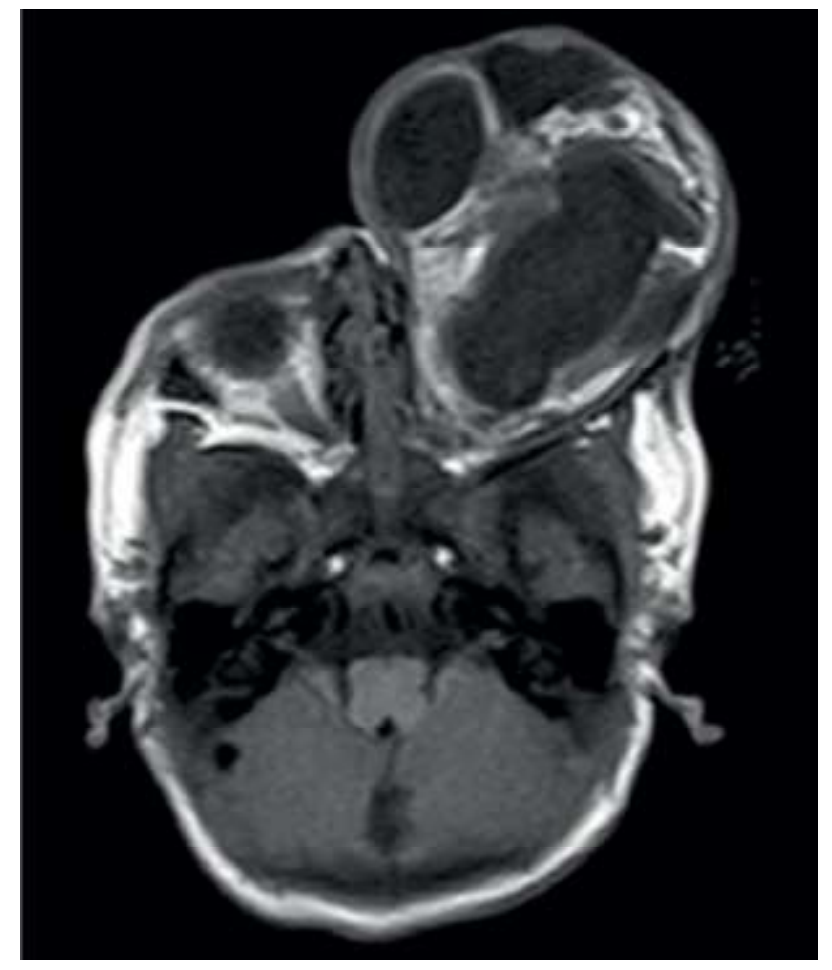

Figure 2. Axial T1-MRI shows the multilocular mass, with liquid and fatty content corresponding with teratoma 


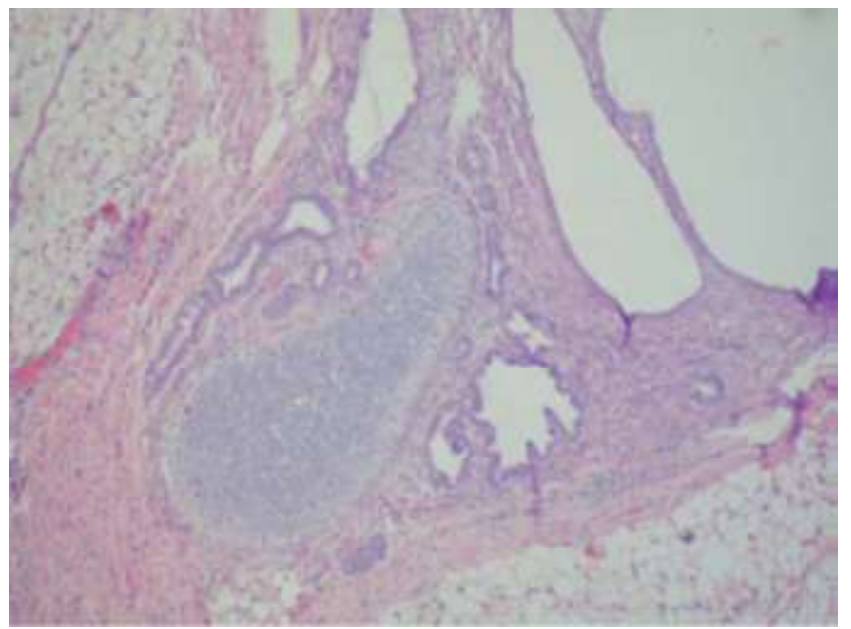

Figure 3. Organoid structures formed by mature cartilage, mature adipose tissue, fibromuscular tissue, and columnar epithelium with cilia. (Hematoxylin and eosin stain, $10 \mathrm{X}$ )

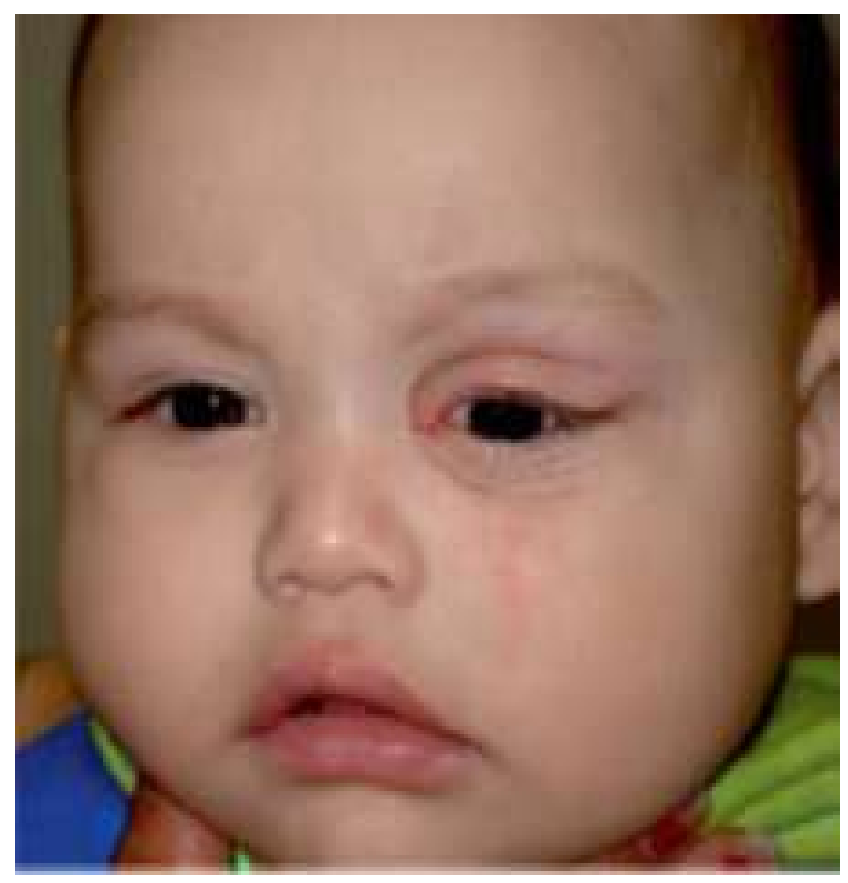

Figure 4. Patient eight months after surgery with ocular prosthesis adapted

consistency, when opened it released plenty of yellow liquid.

Histopathological examination of the mass revealed the presence of cartilage, mature adipose tissue, fibromuscular tissue, respiratory epithelium and gastrointestinal mucosa. A final histopathological diagnosis of mature cystic teratoma was made (Figure 3).
The patient was taken to surgery 15 days after resection of the tumor for a new adaptation of conformer to continue with the cul de sac reconstruction, given that tissues were completely relaxed and had completely lost the normal anatomy. Also, a new tarsorraphy was made.Currently, the patient has adequate cul de sac with a very good cavity and prosthesis was finally adapted with very good cosmetic result (Figure 4).

\section{Discussion}

Teratomas are tumors composed of a wide diversity of tissues foreign to the anatomic site where they arise ${ }^{1}$. They are usually benign, and have been divided into four different groups:

1. Complete orbital fetus-in-fetu (orbitopagus parasiticus).

2. Incomplete second fetus including spine.

3. True orbital teratoma with the three germ layers.

4. Dermoid tumor with only two germ cell lines ${ }^{2}$.

Histopathologically, most teratomas are composed of tissues representing at least two, but usually three embryonic layers, including ectoderm, mesoderm, and endoderm. If the neoplastic tissue is uniformly mature, resembling the adult tissues, the tumor is defined as a mature teratoma. Tumors containing any immature or embryonal tissue with mitotic figures are designated as immature teratomas and can display malignant behavior with metastasis ${ }^{4}$.

The predominant germ cell observed in orbital teratomas is surface ectoderm as cysts filled with keratin and adnexal structures, such as hair follicles and sweat glands. Neuroectodermal tissues include primitive neural tubes, choroidal plexus, ganglia, and glial elements. The mesoderm is the second most common germ cell layer, represented by muscle, bone, cartilage, and fat. The endoderm is the least common component of teratomas and it may produce respiratory or gastrointestinal tissue cysts ${ }^{4}$.

It is more common in women and it has been described more frequently in the left orbit ${ }^{2}$. The clinical features of these tumors include an otherwise 
healthy newborn with extreme unilateral proptosis, marked stretching of the eyelids over a tense, fluctuating mass, elongation of the palpebral fissure, abscense of communication between the cyst and the intracranial cavity, normally developed eye that may exhibit degenerative changes secondary to the displacement by the teratoma, and transillumination of all or part of the orbital mass ${ }^{1}$. Rapid growth after birth is due to accumulation of glandular secretions within cystic spaces. The optic nerve may be encased or adherent to the tumor, leading to secondary atrophy and poor pupil reaction ${ }^{5}$. Other features include no family history of congenital deformities witn nonconsanguineous parents, normal pregnancy and delivery, and no history of teratogenic influences to the mother' ${ }^{1}$.

At imaging, benign orbital teratomas are usually multiloculated, cystic masses with an admixture of tissues including calcification, fat and ossification. They are sharply circumscribed ${ }^{2}$. The differential diagnosis of these tumors include: dermoid cysts, cephalocele, linfangioma, hemangioma and epidermoid inclusion cysts ${ }^{2}$.

The objective in the management of orbital teratoma is to save the eye to encourage orbitofacial development, maintain cosmesis, and retain some vision. Early surgical intervention may allow preservation of the globe and vision in some patients; however, preservation of the globe is not possible if there is no organized eye or optic nerve present, when the tumor engulfs the optic nerve, and there is extreme proptosis, exposure keratopathy and no pupillary reflex ${ }^{1,3}$.

We decided to report this case because it is a very uncommon disorder and there are only a few reports of similar cases in literature. Although it was not posible to retain the eyeball due to penetration, exenteration was not required and the reconstruction process was successful in spite of the great tissue deformity after surgery with a very good cosmetic result.

Conflict of interest. No conflicting relationship exists for any author. The authors have no proprietary or commercial interests in any materials discussed in this article.

\section{References}

1. Gnanaraj L, Skibell BC, Coret-Simon J, Halliday W, Forrest C, DeAngelis DD. Massive congenital orbital teratoma. Ophthal Plast Reconstr Surg. 2005; 21: 445-7.

2. Herman TE, Vachharajani A, Siegel MJ. Massive congenital orbital teratoma. J Perinatol. 2009; 29: 396-7.

3. Mehta M, Chandra M, Sen S, Bajaj MS, Pushker N, Meel $\mathrm{R}$, et al. Orbital teratoma: a rare cause of congenital proptosis. Clin Experiment Ophthalmol. 2009; 37: 626-8.

4. Gündüz K, Kurt RA, Heper AO. Eye-conserving treatment in massive congenital orbital teratoma. Clin Experiment Ophthalmol. 2009; 37: 320-3.

5. Mee JJ, McKelvie PA, McNab AA. Orbital teratoma: late presentation with normal vision. Clin Experiment Ophthalmol. 2002; 30: 41-3. 